\title{
PRZEMYŚL. MIASTO TWIERDZA ORAZ TWIERDZA PRZEMYŚL. RAZEM CZY OSOBNO NA DRODZE DO POMNIKA HISTORII
}

\section{NESTOROW Rafał ${ }^{1}$}

\footnotetext{
1 dr Rafał Nestorow, Instytut Sztuki PAN w Warszawie https://orcid.org/0000-0002-8626-2356
}

ABSTRAKT: W artykule poruszone zostały zagadnienia dotyczące wyboru i trudnej selekcji obiektów zabytkowych z terenu miasta Przemyśla, jakie zostały wybrane do wpisu na listę pomników historii. $\mathrm{Z}$ uwagi na czynniki geograficzno-historyczne zdecydowano się główny akcent położyć na wartość militarną miasta. We wniosku na listę pomników historii, oprócz starego miasta w obrębie pozostałości murów miejskich, wpisano także inkastelowane klasztory karmelitów, reformatów i benedyktynek na Zasaniu, których umocnienia wspierały obronność miasta. Wybrano również znajdujące się na terenie miasta obiekty zaplecza koszarowego Twierdzy. Wszystkie te elementy złożyły się na bardzo rozległy, rozlokowany „wyspowo" na terenie miasta i gmin sąsiednich obszar o zróżnicowanym stopniu zachowania substancji zabytkowej. W tekście poruszono problem rozległości wpisu na listę pomników historii, wartości krajobrazowe i historyczno-artystyczne miasta, zagadnienia ochrony i podniesienia wartości turystycznej, a także postawiono pytanie o dalsze perspektywy rozwoju miasta i Twierdzy.

SŁOWA KLUCZE: Przemyśl, Twierdza Przemyśl, fortyfikacje

Na rocznicę stulecia odzyskania przez Polskę niepodległości, w wyniku starań Prezydenta Miasta Przemyśla i Przewodniczącego Zarządu Związku Gmin Fortecznych Twierdzy Przemyśl, przy wsparciu wójtów gmin fortecznych i Starosty Przemyskiego, Miasto Przemyśl i Twierdza Przemyśl zostały uznane za Pomnik Historii. To nobilitujące wyróżnienie zapoczątkowuje nowy etap w dziejach historii grodu nad Sanem i Twierdzy Przemyśl. Przede wszystkim zaś otwiera nowe perspektywy dalszego rozwoju Przemyśla jako miasta turystycznego, o olbrzymim potencjale i wybitnych walorach krajobrazowych ${ }^{1}$. Dość wspomnieć, że ponad tysiąc lat historii znalazło swoje przełożenie w danych statystycznych. Przemyśl ma największą w Polsce 
ilość zabytków w przeliczeniu na jednego mieszkańca i jednostkę powierzchni ${ }^{2}$ Z uwagi na powyższe czynniki władze miasta w osobie Pana Prezydenta Roberta Chomy, przy wsparciu Podkarpackiego Wojewódzkiego Konserwatora Ochrony Zabytków w Przemyślu Pani Beaty Kot, podjęli starania o przygotowanie dokumentacji umożliwiającej podjęcie starań o wpisanie Przemyśla na listę pomników historii. Gdy na początku 2017 roku ówczesny Prezydent Miasta zwrócił się do mnie z propozycją przygotowania wniosku, podstawowym problemem jaki się pojawił był jego zakres. Oczywiście ówczesnym włodarzom miasta zależało, by ująć we wniosku jak największy obszar, drugim warunkiem było uwzględnienie Twierdzy Przemyśl. Tak postawione wymagania wydawały się niemożliwe do zrealizowania, przede wszystkim z uwagi na rozległość terytorialną, problem w wytyczeniu granic i brak merytorycznego uzasadnienia. Konieczne okazało się takie sformułowanie wniosku umożliwiające ujęcie miasta i Twierdzy, jako dwóch oddzielnych, ale zespolonych ze sobą elementów. Z uwagi na czynniki historycznogeograficzne elementem spajającym obydwa zespoły była wartość militarna miasta. Biorąc pod uwagę również wielokulturowy charakter miasta sformułowano ostateczny temat wpisu, który uwzględniając jego specyfikę pozwalał na określenie elementów wpisu i wyznaczenie jego granic składających się na spójną całość. Ostatecznie temat wpisu brzmiał: Przemyśl. Miasto-twierdza. Zespót staromiejski i Twierdza Przemyśl. Dziedzictwo narodów Europy Środkowej (tabl.1).

Podstawą wpisu stała się staromiejska część miasta w obrębie pozostałości nowożytnych murów miejskich wraz ze wzgórzem zamkowym (fot.1) i zamkiem tzw. Kazimierzowskim oraz inkastelowanymi, nowożytnymi zespołami kościelno-klasztornymi, których obwarowania odgrywały ważną rolę wzmacniającą obronność miasta (fot.2). W pierwszej kolejności wymienić należy zespół kościoła i klasztoru karmelitów bosych, z najlepiej zachowanymi fragmentami murów obronnych, wpisanych $\mathrm{w}$ system nowożytnych umocnień miejskich, następnie usytuowany tuż za dawnymi murami miejskimi przy dawnej Bramie Lwowskiej zespół kościoła i klasztoru reformatów oraz położony na Zasaniu zespół kościoła i klasztoru benedyktynek, broniący dostępu do przeprawy na Sanie. W ramach wpisu uwzględniono również pochodzący z pocz. w. XX zespół kościoła i klasztoru karmelitanek położony w granicach przebiegu ziemnych umocnień miasta, których czytelne fragmenty zachowały się na terenie klasztornym³ ${ }^{3}$.

\footnotetext{
Kot B., I etap projektu pn. „Zagospodarowanie zespołu zabytkowego Twierdzy Przemyśl w celu udostępnienia dla turystyki kulturowej", ścieżka do nobilitacji zabytku jako pomnika historii RP”, [w:] Dawne fortyfikacje dla turystyki, rekreacji i kultury, red. L. Narębski, Toruń 2018, s. 73.

Katalog zabytków sztuki w Polsce, red. nacz. M. Kałamajska-Saeed. Seria nowa, Miasto Przemyśl, cz. 1: Zespoły sakralne, red. J. Sito, oprac. P. Krasny, J. Sito, Warszawa 2004; J. Polaczek, Zamek zwany kazimierzowskim w Przemyślu, Przemyśl 2014; Frazik J.T., Mury obronne Przemyśla w XVI i XVII wieku, [w:] Tenże, Sztuka Przemyśla i Ziemi Przemyskiej, red. M. Dłutek, J. Kowalczyk, Przemyśl-Warszawa 2004, s. 19-30; Kot B., Mury miejskie Przemyśla, „Renowacje i Zabytki”, 2014, nr 2 (50), s. 78-81.
} 


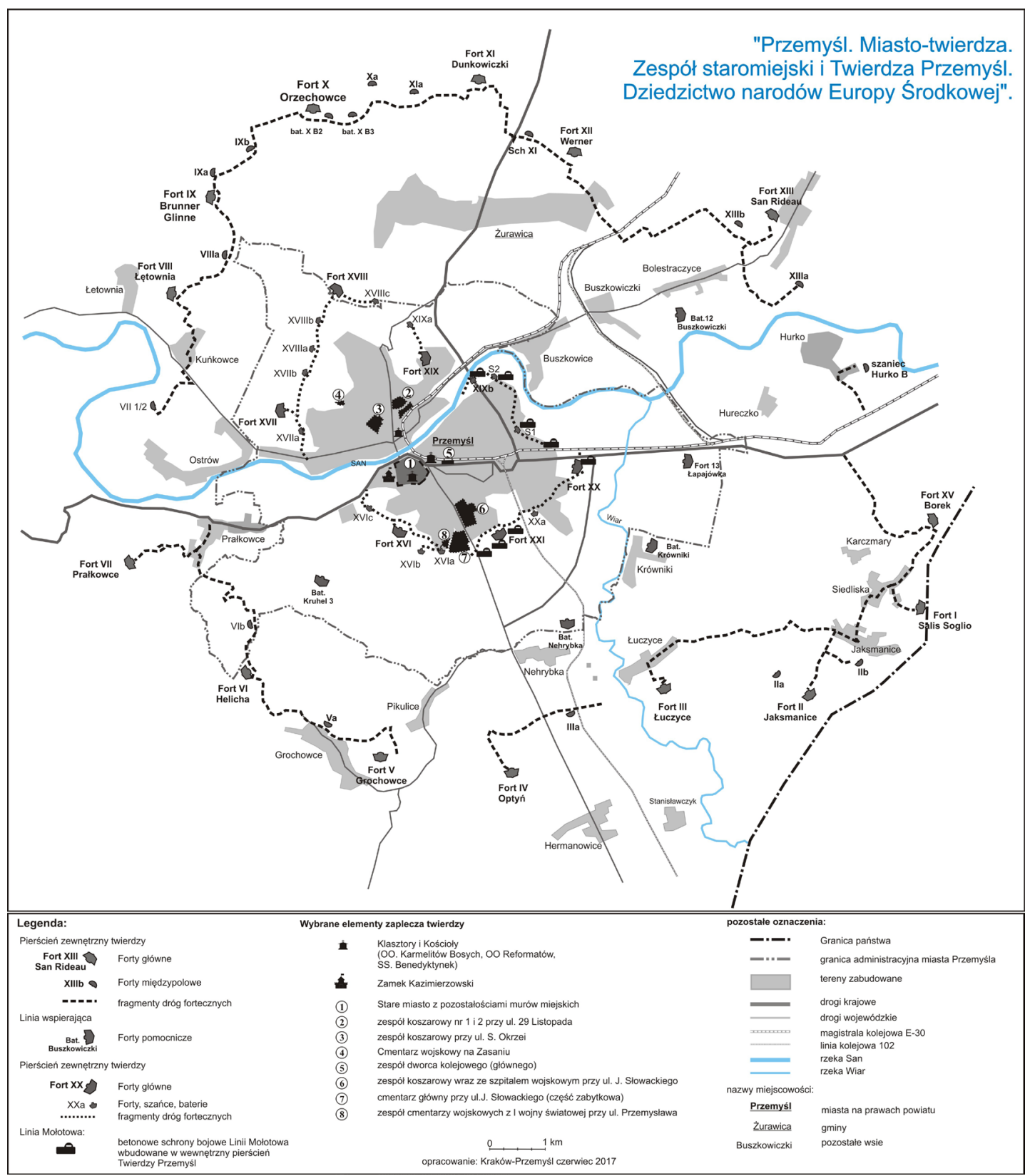

Ryc. 1 „Przemyśl -miasto twierdza. Zespół staromiejski i Twierdza Przemyśl. Dziedzictwo narodów Europy Środkowej”. Schematyczny plan z znaczeniem elementów zabytkowych wchodzących w zakres wpisu na listę pomników historii, oprac. R. Nestorow, rys. J. Ochalski 


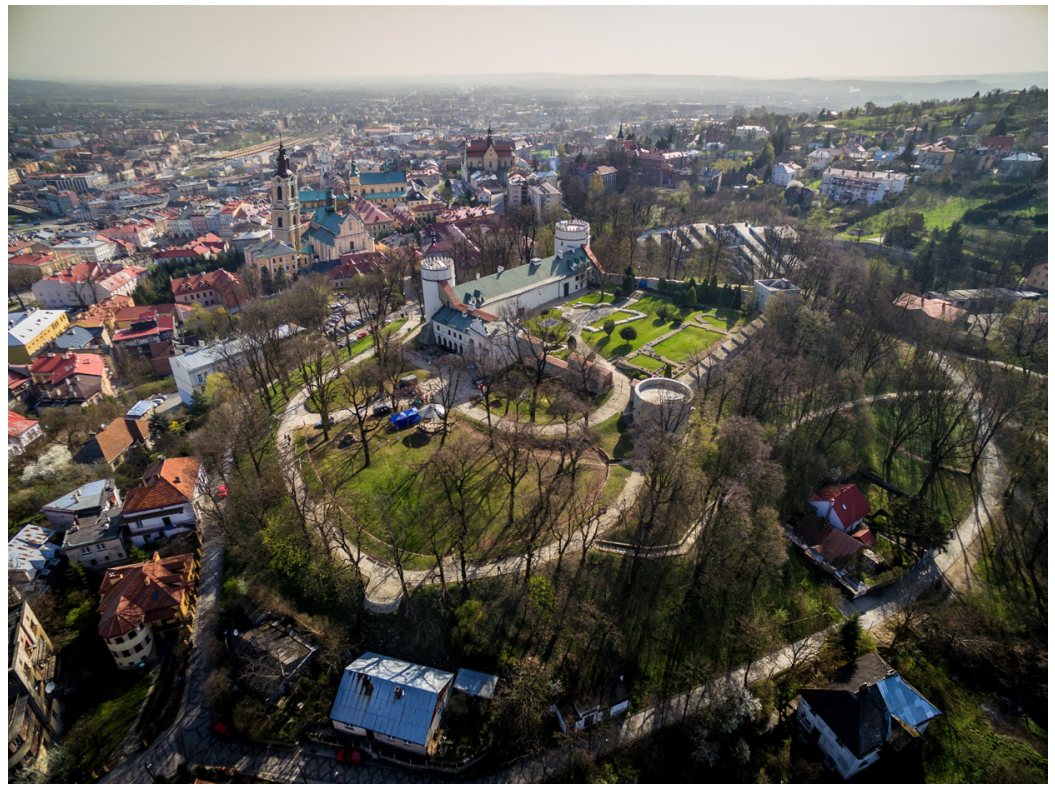

Fot. 1 Zamek w Przemyślu, widok z lotu ptaka od pn.-zach. Poniżej wzgórza, patrząc od lewej najważniejsze świątynie: katedra rzymskokatolicka $\mathrm{z}$ wieżą-dzwonnicą, kościół franciszkanów, kościół jezuitów (obecnie katedra greckokatolicka), kościół karmelitów oraz kościół karmelitanek. Fot. ze zbiorów Urzędu Miejskiego w Przemyślu

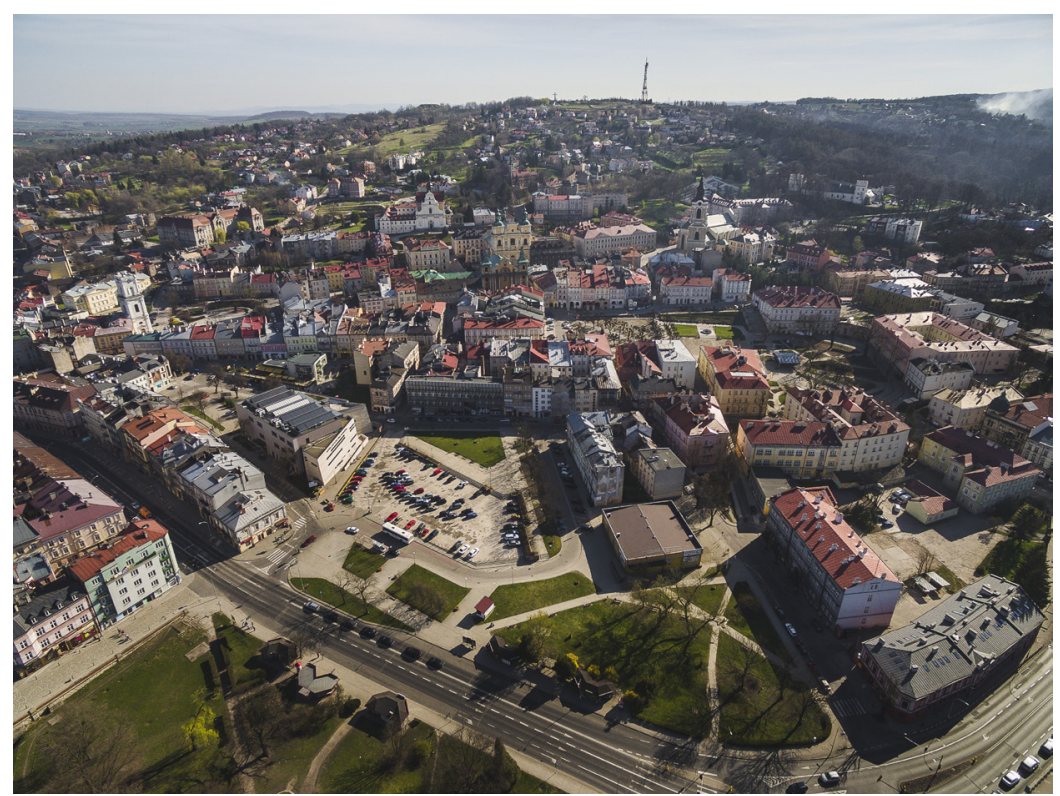

Fot. 2 Przemyśl - część staromiejska, widok od pn. z lotu ptaka ukazujący tarasowy układ zabudowy. Fot. ze zbiorów Urzędu Miejskiego w Przemyślu 
Najwięcej pytań i wątpliwości dotyczyło Twierdzy Przemyśl (1854-1914) ${ }^{4}$. Związane było to ze stanem zachowania obiektów pofortecznych, a przede wszystkim z obszarem, rozległością terytorialną i rozdrobnieniem poszczególnych mniejszych i większych dzieł fortecznych (fot. 3).

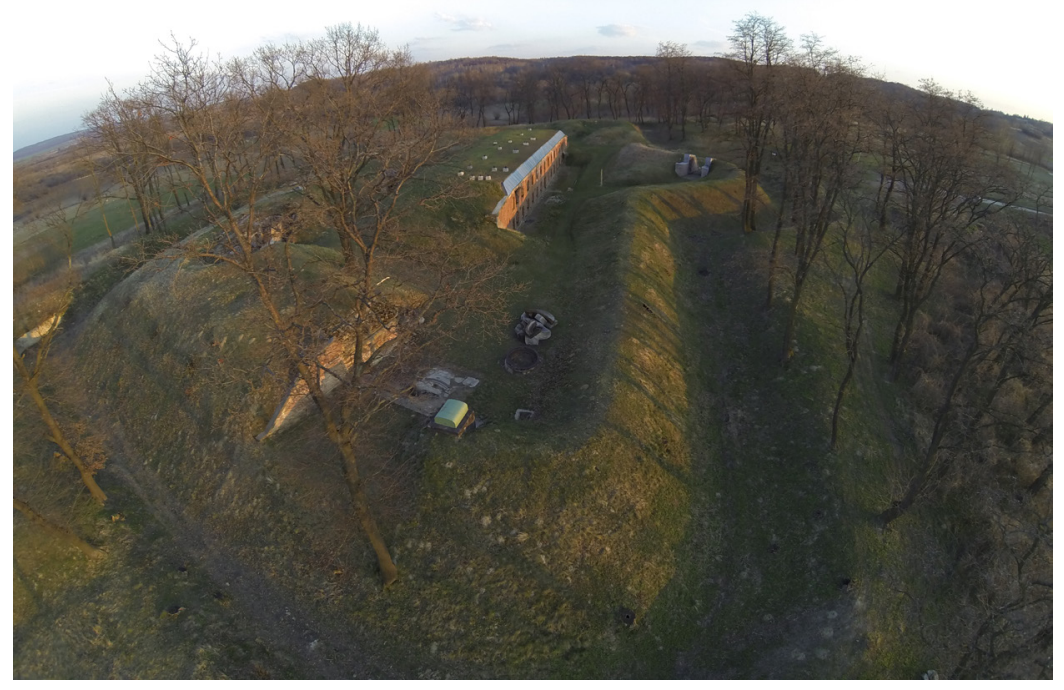

Fot. 3 Fort XV „Borek”, widok z lotu ptaka. Stan po przeprowadzonych pracach rewitalizacyjnych. Fot. ze zbiorów Związku Gmin Fortecznych Twierdzy Przemyśl

Pozostawała również otwarta kwestia ogromnej liczby obiektów zlokalizowanych na terenie miasta, w przeważającej części, usytuowanych poza obrębem staromiejskim, a składających się na zaplecze twierdzy. Pomijając mniej istotne pod względem wartości artystycznych budynki techniczne (baraki, składy itp.), pozostawała znaczna liczba obiektów koszarowych, czy zajmowanych przez dowództwo poszczególnych formacji wojskowych, siedziba komendanta, szpitala garnizonowego, siedziby instytucji wojskowych, kasyno oficerskie, a ponadto całe zaplecze techniczne w postaci dworca kolejowego, akweduktu, zakładów produkcyjnych itp. Ponadto na terenie miasta zachował się unikatowy zespół cmentarzy wojskowych z okresu I wojny światowej przy ul. Przemysława, cmentarz wojenny na Zasaniu przy ul. B. Śmiałego czy posiadający niezwykłe walory krajobrazowe, położony na stokach Zniesienia cmentarz główny, z licznymi nagrobkami mieszkańców Twierdzy, wykonanymi przez najlepsze lokalne pracownie kamieniarskie, a także liczne zakłady ze Lwowa czy Krakowa ${ }^{5}$. Zdając sobie sprawę z powyższych trudności zadecydowano, że pomimo rozległości obszaru pierścieniowej Twierdzy Przemyśl nie można uwzględniać jej wybiórczo, ograniczając się jedynie do kilkunastu wybranych obiektów czy elementów składowych, np. wewnętrznego pierścienia tylko należy potraktować ją jako nierozerwalną całość (z oczywistym pominięciem niewielkiego fragmentu Twierdzy

Idzikowski T., Twierdza Przemyśl. Powstanie-Rozwój-Technologie, Krosno 2014.

Zając I., Cmentarze wojenne z okresu I wojny światowej, Przemyśl 2001; Taż, Aleje pamięci. przemyskie cmentarze, Przemyśl 2004. 
znajdującego się obecnie na terytorium Ukrainy). Zespół zabytkowy dawnej Twierdzy Przemyśl jest usytuowany w czytelnym krajobrazie warownym, jako zespół fortów połączonych układem dróg, z grupami zieleni maskującej, w odpowiednio kształtowanej zabudowie i zespołach leśnych, $\mathrm{z}$ wielkimi zespołami koszarowymi i magazynowymi położonymi na terenie miasta Przemyśla. O unikatowości Twierdzy Przemyśl spośród innych twierdz europejskich, decyduje przede wszystkim czytelny krajobraz warowny, rozumiany też jako krajobraz wielkiego pola bitwy. Świadectwem krwawych bitew z okresu walk o Twierdzę Przemyśl są zachowane na terenie miasta cmentarze wojenne. Przyjęto również, że nie można pozbawić Twierdzy jej zaplecza w postaci budynków zlokalizowanych na terenie miasta. W tym przypadku z uwagi na ich ilość, zróżnicowany stopień zachowania substancji zabytkowej oraz lokalizację w obecnych granicach miasta, zdecydowano się dokonać wyboru, kierując się przede wszystkim stanem zachowania, autentycznością substancji zabytkowej i wartością artystyczną. Z wielu zachowanych budynków zaplecza Twierdzy Przemyśl zdecydowano się uwzględnić przede wszystkim najlepiej zachowane zespoły koszarowe (powstałe w latach 1880-85; zmodernizowane w latach 1895-1914) z uwagi na ich walory urbanistyczne i krajobrazowe: zespół koszarowy przy ul. J. Słowackiego 89 (Zespół koszarowy nr IV „Baraken-Lager No. 4”), zespół szpitala załogowego przy ul. Słowackiego, zespół koszarowy nr 1 i 2 przy ul. 29 Listopada (zespół koszar 45 Pułku Piechoty), zespół koszarowy przy ul. S. Okrzei (zespół koszar 10 Batalionu Pionierów), a ponadto zespół dworca kolejowego (fot. 4), którego powstanie (1859-1860) i gruntowana rozbudowa (1895) były związane z budową Twierdzy i rozwojem urbanistycznym miasta ${ }^{6}$. Dopełnieniem przyjętej we wniosku narracji, według której czynnikiem determinującym dla historii i urbanistycznego rozwoju miasta od momentu jego założenia były kwestie obronności, było uwzględnienie również fragmentu umocnień tzw. Linii Mołotowa, w postaci betonowych schronów bojowych (BSB) wbudowanych wtórnie w latach 1940-41 w fortyfikacje wewnętrznego pierścienia Twierdzy.

Wybrane elementy złożyły się na bardzo rozległy, rozlokowany „wyspowo” na terenie miasta i gmin sąsiednich, obszar o zróżnicowanym stopniu zachowania substancji zabytkowej (tabl.1). W efekcie czego w trakcie przygotowywania wniosku pojawiało się wiele problemów, począwszy od konieczności uzupełnienia wpisów do rejestru zabytków nieuwzględnionych fragmentów Twierdzy, weryfikacji przebiegu niezachowanych części obwarowań miejskich, czy uregulowaniu granic wpisów elementów Twierdzy i jej zaplecza. Nie mniej trudności nastręczyło przygotowanie ponad stu załączników graficznych, nie wspominając już o kwestiach historycznych tak zróżnicowanego i rozległego zespołu, którego złożona problematyka była trudną do okiełznania sztywnymi ramami wniosku.

6 Jurjewicz H., Przemyśl-dworzec kolejowy. Prace remontowo konserwatorskie 2009-2011, „Renowacje i Zabytki”, 2014, $\operatorname{nr} 2$ (50), s. 101-107. 


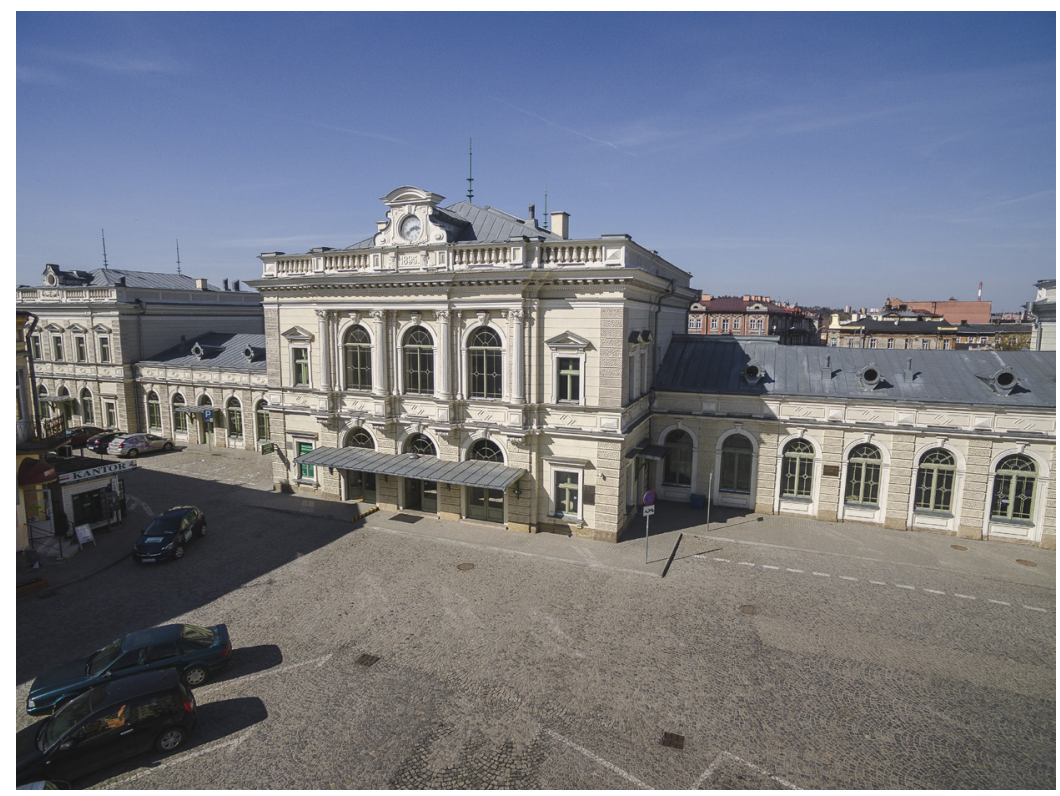

Fot. 4 Dworzec główny w Przemyślu. Widok z lotu ptaka od pd.-wsch.

Fot. ze zbiorów Urzędu Miejskiego w Przemyślu

Opracowanie tak szeroko zakrojonego wniosku, obejmującego rozległy teren Twierdzy Przemyśl zlokalizowany na obszarze dziewięciu gmin powiatu przemyskiego, nie byłoby możliwe, gdyby nie powołany w r. 2008 Związek Gmin Fortecznych Twierdzy Przemyśl zrzeszający dziewięć gmin powiatu przemyskiego ${ }^{7}$. Powołanie Związku umożliwiło realizację unikatowego w skali kraju projektu zagospodarowania części Twierdzy Przemyśl. W latach 2007-2013 zrealizowano I etap projektu Zagospodarowanie zespołu zabytkowego Twierdzy Przemyśl w celu udostępnienia dla turystyki kulturowej. Koszt projektu wyniósł 22071 887,89 zł, w tym wysokość kosztów kwalifikowanych 20761471,39 zł. W projekcie wykonano prace na 24 obiektach dziedzictwa kulturowego. Na podstawie prognoz przewidziano, że rocznie odwiedzi obiekty ponad 14 tys. turystów. W wyniku projektu udostępniono około 20\% Twierdzy Przemyśl. Działania te zostały docenione w r. 2016 w ramach konkursu Ministra Kultury i Dziedzictwa Narodowego i Generalnego Konserwatora Zabytków - Zabytek Zadbany, i przyznano Związkowi Gmin Fortecznych Twierdzy Przemyśl wyróżnienie w kategorii rewaloryzacji przestrzeni kulturowej i krajobrazu ${ }^{8}$.

Zrealizowany projekt udostępnienia części zespołu Twierdzy Przemyśl był pierwszym krokiem do nobilitacji zabytku jako pomnika historii. Kolejnym może być wpis na Listę UNESCO $\mathrm{w}$ ramach wpisu transgranicznego fortyfikacji austrowęgierskich. Idea ta pojawiła się już w 2003 r. podczas Międzynarodowego Dnia Ochrony Zabytków w Krakowie, powrócono do niego ponownie w 2010 r. na posiedzeniu Komitetu ds. Światowego Dziedzictwa w Warszawie.

\footnotetext{
$7 \quad$ http://www.fortytwierdzyprzemysl.pl.

8 http://www.fortytwierdzyprzemysl.pl/index.php/projekty/196-zagospodarowanie-zespolu-zabytkowegotwierdzy-przemysl-w-celu-udostepnienia-dla-turystyki-kulturowej-etap-i.
} 
W 2017 roku w Krakowie doszło do spotkania Prezydentów Krakowa i Przemyśla oraz Wojewódzkich Konserwatorów Zabytków Małopolskiego i Podkarpackiego. Inicjatywa została przedstawiona i zyskała akceptację na spotkaniu przewodniczących parlamentów państw Grupy Wyszehradzkiej w Przemyślu w ubiegłym roku9. Potencjalny wpis stwarza ogromną szansę dla rozwoju turystyki nie tylko na obszarze Twierdzy, ale i miasta Przemyśla. Jak słusznie zauważyła Beta Kot, Podkarpacki Wojewódzki Konserwator Zabytków: „Twierdza jest określana fenomenem w skali kraju, a nawet Europy Środkowej, ponieważ spełnia warunki tzw. „wartości wyjątkowej i uniwersalnej”. „Wyjątkowej”, ponieważ nigdzie w Polsce nie ma tak dużego zespołu urbanistyczno-obronnego, będącego jednocześnie odzwierciedleniem osiągnięć technicznych epoki oraz polem bitwy o znaczeniu strategicznym dla historii Europy. „Uniwersalnej” gdyż jest świadectwem nie tylko historii regionu, lecz również Europy i świata" ${ }^{10}$. Ponadto z uwagi na dobrze zachowany „krajobraz warowny” Twierdzy Przemyśl, spełnia przyjęty w systemie światowego dziedzictwa warunek zespolonej ochrony dóbr kultury i natury ${ }^{11}$. Co istotne, fortyfikacje Twierdzy Przemyśl znajdujące się w przeważającej większości na terytorium Polski, $\mathrm{z}$ niewielkim fragmentem leżącym na Ukrainie, nie powinny być traktowane jednostkowo lecz jako ważny element fortyfikacji austriackiej i austro-węgierskiej stanowiących ważny element dziedzictwa krajów Europy Środkowej, Południowej i Wschodniej (Włochy, Austria, Czechy, Polska, Słowacja, Węgry, Ukraina, Rumunia, Serbia, Czarnogóra, Bośnia, Chorwacja i Słowenia). Fortyfikacja austro-węgierska spełnia kryterium uniwersalności jako reprezentatywny przykład przeglądu większości szkół i odmian fortyfikacji europejskiej. Twierdze pierścieniowe prezentują wyjątkową koncepcję nowoczesnego obozu warownego, jako wyniku myśli inżynierskiej XIX stulecia, rozwiązań technicznych będących dorobkiem przedstawicieli wielu narodów europejskich. Zróżnicowany stan zachowania fortyfikacji austro-węgierskich ma charakter zapisu wydarzeń wojennych, jak było np. w Twierdzy Przemyśl. Realizowane w Twierdzach Przemyśl, Kraków, czy we Włoszech (Folgaria-Lavarone) i na Ukrainie (Twierdza Komarno) projekty mają na celu zachowanie i właściwą adaptację zabytków fortyfikacyjnych i ich udostępnienie dla europejskiego ruchu turystycznego.

Specyfika fortyfikacji wymaga wpisu wielu transgranicznych wpisów na Listę światowego dziedzictwa UNESCO. Ma to już swoje precedensy, np. we wpisie fortyfikacyjnych dzieł Vaubana czy transgranicznym wpisie weneckich dzieł obronnych z wieku XVI i XVII. Wpisanie fortyfikacji austro-węgierskich na Listę światowego dziedzictwa może być kontynuacją już rozpoczętej drogi ${ }^{12}$. Fortyfikacje austro-węgierskie mogą być postrzegane jako transgraniczne i transnarodowe dziedzictwo zespolone, a $\mathrm{z}$ uwagi na lokalne zróżnicowanie, $\mathrm{w}$ tym stan zachowania, można zespolić je np. jako szlak dziedzictwa (Europejski szlak fortyfikacji austro-

\footnotetext{
9 https://przemysl.pl/46346/twierdza-przemysl-na-liscie-unesco.html.

$10 \quad$ Kot B., op. cit., s. 82.

11 Szmygin B., Światowe dziedzictwo UNESCO z perspektywy 40 lat, „Ochrona Zabytków”, 2013, nr 4, s. 168 170; Tenże, Światowe Dziedzictwo Kultury UNESCO - charakterystyka, metodologia, zarzadzanie, Warszawa Lublin 2016, s. 49- 52,115-134.

12 Wielgus K., Środulska-Wielgus J., Wyjątkowe i uniwersalne wartości dawnych krajobrazów warownych, „Teka Komisji Urbanistyki i Architektury PAN, Oddział w Krakowie”, T. XLVI, 2018, s. 431-477.
} 
wegierskich). Na tle europejskich twierdz pierścieniowych trzeba szczególnie podkreślić unikatowość zrealizowanego $\mathrm{w}$ latach 2013-2015 projektu zagospodarowania Twierdzy Przemyśl. Przyczyniło się to do podniesienia wartości zespołu, stanu jego zachowania, zrównoważonego rozwoju przez turystykę kulturową, a przede wszystkim podkreślenia wyjątkowej i uniwersalnej wartości krajobrazu XIX-wiecznych twierdz pierścieniowych, jako ważnego elementu światowego dziedzictwa.

W ramach artykułu nie sposób choćby skrótowo przedstawić złożonej problematyki historyczno-artystycznej składającej się na bogate dziedzictwo Przemyśla i Twierdzy Przemyśl. Można jedynie pokusić się o wskazanie w punktach na najważniejsze elementy składające się na materialne i niematerialne dziedzictwo Przemyśla i Twierdzy Przemyśl.

- Dziedzictwo kulturowe Przemyśla, to świadectwo potęgi, barwności i różnorodności kulturowej dawnej Rzeczypospolitej, czytelne w krajobrazie, zabytkach i zachowanym genius loci miasta.

- Miasto $\mathrm{z}$ dobrze zachowaną substancją zabytkową, której zharmonizowane nawarstwienia są świadectwem wielowiekowej, wielokulturowej i wielonarodowościowej ponad 1000-letniej historii.

- Unikatowy zespół rotundy i palatium na wzgórzu zamkowym z czasów wczesnopiastowskich i rodzącego się na ziemiach ówczesnej Polski chrześcijaństwa.

- Zachowany, czytelny układ przestrzenny miasta z fragmentarycznie zachowanymi odcinkami murów miejskich, których przebieg jest widoczny w strukturze miejskiej zabudowy.

- Tarasowe położenie miasta ponad doliną Sanu wraz z zagęszczeniem historycznej zabudowy składają się na unikalną, malowniczą panoramę miasta, która w niemal niezmienionej formie przetrwała ponad 250 lat .

- Ukształtowanie miasta wraz z nagromadzeniem zabytków architektury sakralnej, przede wszystkim barokowych kościołów i zespołów kościelno-klasztornych sprawiły, że Przemyśl zyskał miano „małego Rzymu”.

- Strategiczne położenie Przemyśla przesądziło o przekształceniu miasta (1854-1914) w jedną z głównych twierdz na terenie cesarstwa, największą w Galicji, trzecią co do wielkości w Europie, jako jedyną trzykrotnie obleganą, wyróżniającą się najdłuższym oblężeniem w oderwaniu od stałego frontu (173 dni).

- Twierdza Przemyśl to spójny zespół pozostałości fortyfikacji z czasów I wojny światowej z zachowanymi budynkami zaplecza twierdzy (koszary, szpital wojskowy, stacje kolejowe itd.) oraz zespołem cmentarzy z I wojny światowej. Elementem wyróżniającym zespół Twierdzy Przemyśl na tle innych twierdz polskich czy europejskich jest zachowany w dobrym stanie zróżnicowany krajobraz warowny na obszarze zewnętrznego pierścienia umocnień.

- Z uwagi na strategiczne położenie Przemyśla, czynnikiem decydującym o rozwoju miasta była jego obronność, poczynając od wczesnośredniowiecznego grodu, następnie murowanego zamku, zespołu umocnień miejskich i inkastelowanych klasztorów, Twierdzy Przemyśl, a skończywszy na odcinku sowieckich bunkrów linii Mołotowa. 
- Zabudowa miasta z przełomu XIX/XX w. o eklektyczno-secesyjnym charakterze harmonizuje z barokowymi fasadami kościołów i zespołów klasztornych i składa się na malowniczą całość.

- Unikatowe elementy wystroju świątyń, a przede wszystkim zespoły późnobarokowej snycerki rzeźby kręgu lwowskiego, jedne z największych i najważniejszych zespołów w granicach obecnej Polski.

- Na przełomie XIX i XX wieku miasto było prężnym ośrodkiem życia kulturalnego i społecznego Małopolski Wschodniej, zabytki tego okresu dokumentują przenikanie się kultur i bogactwo odniesień europejskich inspiracji.

- Lokalizacja miasta sprawiła, że Przemyśl odegrał znaczącą rolę w historii Polski, przede wszystkim $\mathrm{w}$ obydwu wojnach światowych. W wymiarze dziedzictwa materialnego i niematerialnego jest świadectwem polskich dróg do niepodległości oraz zagrożeń dotykających nasz kraj.

Niewątpliwie nobilitacja Przemyśla i Twierdzy Przemyśl dwoma odrębnymi wpisami na listę pomników historii to nie tylko wyróżnienie, ale droga do promocji obydwu zespołów zabytkowych i szansa na ożywienie turystyki kulturowej w mieście i regionie. Na podniesienie walorów turystycznych miasta wpłyną prowadzone obecnie prace konserwatorskie, m.in. przy monumentalnej fasadzie kościoła franciszkanów, która stanowi wyraźny element w panoramie miasta (fot. 1, 2), a przede wszystkim prace przy udostępnieniu rotundy p.w. Św. Mikołaja pod prezbiterium katedry przemyskiej, która stanowić będzie ukoronowanie prac związanych z udostępnionymi już podziemiami katedry i eksponowaną tamże wystawą funeraliów ${ }^{13}$. Jeszcze bardziej spektakularnym przedsięwzięciem jest prowadzony projekt powiększenia podziemnej trasy turystycznej (udostępnionej w 2015 r.) pod Rynkiem ${ }^{14}$. Projekt, którego realizacja przypada na lata 2019-2021 realizowany jest przez gminę miejską Przemyśl przy współpracy Muzeum Narodowego Ziemi Przemyskiej. Projekt jest finansowany w ramach Regionalnego Programu Operacyjnego Województwa Podkarpackiego na lata 2014-2020, Oś priorytetowa VI Spójność Przestrzenna i Społeczna, Działanie 6.3 Rewitalizacja przestrzeni regionalnej. Jego całkowita wartość to $13052469,76 \mathrm{zl}$, a dofinansowanie wyniesie 8726 313,37 zł. W projekcie założono ukazanie w nowoczesny sposób miasta z przełomu XVI i XVII wieku, a więc jego największego rozkwitu. Dodatkową atrakcją ma być przejście XIX-wiecznym kolektorem sanitarnym i dobudowanym łącznikiem do oddziału Muzeum Narodowego w kamienicy Rynek 9/Serbańska $7^{15}$.

\footnotetext{
Stojak G., Podziemia bazyliki archikatedralnej w Przemyślu i ich rewitalizacja w latach 2009-2015, Rzeszów 2017; Drążkowska A., XVIII-wieczna kultura funeralna. Wystawa w przemyskiej archikatedrze, „Renowacje i Zabytki”, 2014, nr 2 (50), s. 65-67.

14 Stojak G., Podziemny Przemyśl. Podziemna Trasa Turystyczna, „Renowacje i Zabytki”, 2014, nr 2 (50), s. $82-83$

15 https://przemysl.pl/52541/mamy-pieniadze-na-podziemna-trase-turystyczna.html.
} 
Można mieć nadzieję, że prowadzone prace nad uczytelnieniem i udostępnieniem kolejnych fortów Twierdzy również przyczynią się do zwiększenia ich waloru turystycznego ${ }^{16}$.

Wpis Przemyśla na listę pomników historii pobudził miejscowe władze do działania na rzecz ochrony i wykorzystania największego potencjału miasta jakim jest jego wielowiekowe dziedzictwo. W lutym bieżącego roku obecny Prezydent Miasta Pan Wojciech Bakun podpisał rozporządzenie, powołując zespół do prac nad utworzeniem w Przemyślu Parku Kulturowego, którego proponowany obszar terytorialny jest większy niż zakres wpisu Starego Miasta na listę pomników. Kolejnym krokiem nad utworzeniem parku kulturowego była konferencja zorganizowana 8 maja b.r. w Muzeum Narodowym Ziemi Przemyskiej w ramach kampanii społecznej „Krajobraz mojego miasta” organizowanej przez Narodowy Instytut Dziedzictwa ${ }^{17}$.

Można mieć nadzieję, że wyróżnienia miasta i Twierdzy Przemyśl dwoma odrębnymi wpisami na listę pomników historii, wzmocni zarówno u mieszkańców jak i włodarzy poczucie dumy i odpowiedzialności za otaczające ich dziedzictwo, które powinno być najważniejszym elementem dla rozwoju i ożywienia całego regionu.

${ }_{16}$ Środulska-Wielgus J., Wielgus K., Twierdza Przemyśl. Warowny krajobraz turystyczny, „Renowacje i Zabytki", 2014, nr 2 (50), s. 114-123.

17 https://przemysl.pl/53836/odbyla-sie-konferencja-w-ramach-kampanii-krajobraz-mojego-miasta.html. 


\section{Bibliografia:}

Drążkowska A., (2014). XVIII-wieczna kultura funeralna. Wystawa w przemyskiej archikatedrze, „Renowacje i Zabytki”, nr 2 (50), s. 65-67.

Frazik J.T., (2004). Mury obronne Przemyśla w XVI i XVII wieku, [w:] red. M. Dłutek, J. Kowalczyk. Sztuka Przemyśla i Ziemi Przemyskiej, Przemyśl-Warszawa, s. 19-30.

Idzikowski T., (2014). Twierdza Przemyśl. Powstanie-Rozwój-Technologie, Krosno.

Jurjewicz H., (2014). Przemyśl-dworzec kolejowy. Prace remontowo konserwatorskie 2009-2011. Renowacje i Zabytki, nr 2 (50), s. 101-107.

Katalog zabytków sztuki w Polsce (2014). red. nacz. M. Kałamajska-Saeed. Seria nowa, Miasto Przemyśl, cz. 1: Zespoły sakralne, red. J. Sito, oprac. P. Krasny, J. Sito, Warszawa.

Kot B., (2014). Mury miejskie Przemyśla, Renowacje i Zabytki, nr 2 (50), s. 78-81.

Kot B., (2018). I etap projektu pn. „Zagospodarowanie zespołu zabytkowego Twierdzy Przemyśl w celu udostępnienia dla turystyki kulturowej", ścieżka do nobilitacji zabytku jako pomnika historii $R P$ ", [w:] Dawne fortyfikacje dla turystyki, rekreacji i kultury, red. L. Narębski, Toruń, s. 73-82.

Piekarz T., (2014). Panorama Przemyśla, Renowacje i Zabytki, nr 2 (50), s. 36-43.

Polaczek J., (2014). Zamek zwany kazimierzowskim w Przemyślu, Przemyśl.

Stojak G., (2014). Podziemny Przemyśl. Podziemna Trasa Turystyczna, Renowacje i Zabytki, nr 2 (50), s. 82-83.

Stojak G., (2017). Podziemia bazyliki archikatedralnej w Przemyślu i ich rewitalizacja w latach 2009-2015, Rzeszów.

Szmygin B., (2013). Światowe dziedzictwo UNESCO z perspektywy 40 lat, „Ochrona Zabytków”, nr 4, s. 169-179.

Szmygin B., (2016). Światowe Dziedzictwo Kultury UNESCO - charakterystyka, metodologia, zarzadzanie, Warszawa Lublin.

Środulska-Wielgus J., Wielgus K., (2014). Twierdza Przemyśl. Warowny krajobraz turystyczny. Renowacje i Zabytki, nr 2 (50), s. 114-123.

Wielgus K., Środulska-Wielgus J., (2018). Wyjątkowe i uniwersalne wartości dawnych krajobrazów warownych, , Teka Komisji Urbanistyki i Architektury PAN, Oddział w Krakowie”, T. XLVI, s. 431-477.

Zając I., (2001). Cmentarze wojenne z okresu I wojny światowej, Przemyśl.

Zając I., (2004). Aleje pamięci. Przemyskie cmentarze, Przemyśl. 


\section{Strony internetowe:}

https://przemysl.pl/53836/odbyla-sie-konferencja-w-ramach-kampanii-krajobraz-mojegomiasta.html.

https://przemysl.pl/52541/mamy-pieniadze-na-podziemna-trase-turystyczna.html.

http://www.fortytwierdzyprzemysl.pl.

http://www.fortytwierdzyprzemysl.pl/index.php/projekty/196-zagospodarowanie-zespoluzabytkowego-twierdzy-przemysl-w-celu-udostepnienia-dla-turystyki-kulturowej-etap-i.

https://przemysl.pl/46346/twierdza-przemysl-na-liscie-unesco.html. 
